Thinking the Body as a Basis, Provocation, and Burden of Life 


\section{Challenges of Life}

Essays on philosophical and cultural anthropology

Edited by

Gert Melville and Carlos Ruta

\section{Volume 2}




\section{Thinking the Body as a Basis, Provocation, and Burden of Life}

Studies in Intercultural and Historical Contexts

Edited by

Gert Melville and Carlos Ruta

Editorial Manager

Laura S. Carugati 
ISBN 978-3-11-040731-0

e-ISBN (PDF) 978-3-11-040738-9

e-ISBN (EPUB) 978-3-11-040747-1

\section{Library of Congress Cataloging-in-Publication Data}

A CIP catalog record for this book has been applied for at the Library of Congress.

\section{Bibliografische Information der Deutschen Nationalbibliothek}

The Deutsche Nationalbibliothek lists this publication in the Deutsche Nationalbibliografie; detailed bibliographic data is available in the internet at http://dnb.dnb.de.

(C) 2015 Walter de Gruyter GmbH, Berlin/Boston

Typesetting: Dr. Rainer Ostermann, München

Printing: CPI books GmbH, Leck

(2) Printed on acid-free paper

Printed in Germany

www.degruyter.com 